MIDPI

sciforum
MOL2NET, International Conference Series on Multidisciplinary Sciences UDLABIOTECH-01: I International Biotechnology Congress of Universidad de Las Américas (UDLA), Quito, Ecuador

\title{
Genetic diversity and population structure of the yellowfin tuna (Thunnus albacares) comparing samples collected in artisanal fisheries of Ecuador and Mexico using microsatélite loci
}

Terán-Velástegui M. ${ }^{a}$, Torres, ML. ${ }^{a}$, Galván Magaña, F. ${ }^{b}$, Canty S. ${ }^{c}$, Muñoz Abril L. $a$

${ }^{a}$ Universidad San Francisco de Quito (USFQ), Colegio de Ciencias Biológicas y Ambientales,

Laboratorio de Biotecnología Vegetal, Campus Cumbayá, Quito, Ecuador.

${ }^{b}$ Centro Interdisciplinario de Ciencias Marinas (CICIMAR), La Paz, México.

${ }^{c}$ Smithsonian Institute, Washington D.C., United States.

\section{Graphical Abstract}

Insert grafical abstract figure here

\section{Abstract.}

The yellowfin tuna (Thunnus albacares) is a bony fish belonging to the Scombridae family. It is found on tropical and subtropical pelagic waters around the world. Thunnus albacares, particularly, is a species of high economic, ecologic and social value as it supports a relevant sector of the fishery industry [1]. Therefore, ensure an adequate management of this resource is necessary to maintain both sustainability and commercial trade [2][3]. Moreover, as an apex predator, the conservation of the yellowfin tuna is relevant for the preservation of healthy marine ecosystems and prevent the loss of this species [4]. However, to date multiple mismatches between management units and biological populations have been reported in the case of the yellowfin tuna in different regions of the world. These mismatches put in danger the correct management of the marine resource [5][6]. Specifically in the Eastern Pacific Ocean, previous studies have suggested genetic differences between northern and equatorial samples [7][8]. Thus, the objective established in the present study was to characterize the genetic diversity and population structure of Thunnus albacares in a section of the Eastern Pacific. We collected 630 samples from artisanal fisheries of Ecuador and Mexico in three distinct years (2015-2017). The samples were molecularly characterized using 18 
microsatellite loci. The expected heterozygosity index (HE $=0.85)$ together with an allelic richness per locus of 18.40 showed a high genetic diversity in the sample analyzed. No population structure was found, although low genetic differences were found between samples from Mexico and Ecuador (FST < 0.02). The low genetic differentiation found was statistically significant $(\mathrm{P}<0.05)$. Low levels of relatedness as well as the detection of first generation migrants suggest continuous gene flow in the section of the Eastern Pacific Ocean analyzed. The results support the concordance between one biological population and the actual management unit administrated by the InterAmerican-Tropical-Tuna-Commission (IATTC). However, model-based clustering STRUCTURE results also show a slight difference in the genetic pools composition of northern and equatorial samples. Additionally, differences between the genetic pool of samples collected in the same region in different years suggest temporal changes in allelic frequencies or the dependence of the collection on fishery effort. It is recommended to continue the monitoring of $T$. albacares in the Eastern Pacific Ocean, specially taking into account the actual diminish of tuna populations worldwide [9]. Future studies should consider the inclusion of samples from higher latitudes where geographical barriers like the California and Humboldt [10] cold currents occur. In addition, new approaches such as second generation sequencing analyze a greater proportion of the genome and they can provide new information that contribute to the development of better management plants for T. albacares in the fishery industry [11].

Key words: Genetic diversity, stock, microsatellite markers, fisheries management, yellowfin tuna.

\section{Introduction (optional)}

Materials and Methods (optional)

\section{Results and Discussion (optional)}


Conclusions (optional)

References (mandatory)

[1] Pecoraro, C., Zudaire, I., Bodin, N., Murua, H., Taconet, P., Díaz-Jaimes, P., Cariani, A. \& Chassot, E. (2017). Putting all the pieces together: integrating current knowledge of the biology, ecology, fisheries status, stock structure and management of yellowfin tuna (Thunnus albacares). Review Fish Biology Fisheries, 27, 811-841.

[2] IATTC. (2018). Report on the tuna fishery, stocks, and ecosystem in the Eastern Pacific Ocean in 2018. Retrieved from http://www.iattc.org/PDFFiles/FisheryStatusReports/_English/No-172019_Tuna\%20fishery,\%20stocks, \%20and\%20ecosystem\%20in\%20the\%20eastern\%20Pacific \%20Ocean\%20in\%202018.pdf

[3] Block, B., Jonsen, I., Jorgensen, S., Winship, A., Shaffer, S., Brogad, S., Hazen, D., Foley, D., Breed, G., Harrison, A., Ganong, J., Swithenbank, A., Castleton, M., Dewar, H., Mate, B., Shillinger, G., Schaefer, K., Benson, S., Weise, M., Henry, R. \&Costa, D. (2011). Tracking apex marine predator movements in a dynamic ocean. Nature, 475, 86-90.

[4] Aguila, R., Perez, S., Catacutan, B., Lopez, G., Barut, N., \& Santos, M. (2015). Distinct Yellowfin Tuna (Thunnus albacares) Stocks Detected in Western and Central Pacific Ocean (WCPO) Using DNA Microsatellites. PLOS One, 1-14.

[5] Mullins, R., McKeown, N., Sauer, W., \& Shaw, P. (2018). Genomic analysis reveals multiple mismatchs between biological and management units in yellowfin tuna (Thunnus albacares). ICES Journal of Marine Science, 1-8.

[6] Díaz-Jaimes, P., \& Uribe-Alcocer, M. (2006). Spatial differentition in the eastern Pacific yellowfin tuna revealed by microsatellite variation. Fisheries Science, 72, 590-596.

[7] IATTC. (2018). Tunas, Billfishes and other pelagic species in the Eastern Pacific Ocean in 2017. Retrieved from https://www.iattc.org/PDFFiles/FisheryStatusReports/_English/No-162018_Tunas\%20billfishes\%20and\%20other\%20pelagic\%20species\%20in\%20the\%20eastern\% 20Pacific\%20Ocean\%20in\%202017.pdf

[8] Antoni, L., Luque, P., Naghshpour, K., \& Saillant, E. (2014). Polymorphic microsatellite markers for the Yellowfin tuna (Thunnus albacares). Conservation Genetic Resources, 6, 609-611.

[9] Pecoraro, C. (2016). Global population genomic structure and life history trait analysis of yellowfin tuna (Thunnus albacares). [TESIS DE POSGRADO].

[10] Dammannagoda, S., Hurwood, D., \& Mather, P. (2008). Evidence for fine geographical scale heterogeneity in gene frequencies in yellowfin tuna (Thunnus albacares) from the north Indian Ocean around Sri Lanka. Fisheries Research, 90(1), 147-157.

[11] Aguila, R., Perez, S., Catacutan, B., Lopez, G., Barut, N., \& Santos, M. (2015). Distinct Yellowfin Tuna (Thunnus albacares) Stocks Detected in Western and Central Pacific Ocean (WCPO) Using DNA Microsatellites. PLOS One, 1-14.

[12] Davies, C., Gosling, E., Was, A., Brophy, D., \& Tysklind, N. (2011). Microsatellite analysis of albacore tuna (Thunnus alalunga): population genetic structure in the North-East Atlantic Ocean and Mediterranean Sea. Marine Biology, 158 (12), 2727-2740. 
[13] Takagi, M., Okamura, T., Chow, S., \& Taniguchi, N. (2001). Preliminary study of albacore (Thunnus alalunga) stock differentiation inferred from microsatellite DNA analysis. Fishery Bulletin-National Oceanic and Atmospheric Administration, 99 (4), 697-701.

[14] DeWoody, J., \& Avise, J. (2000). Microsatellite variation in marine, freshwater and anadromous fishes compared with other animals. Journal of fish biology, 56(3), 461-473.

[15] Knutsen, H., Olsen, E., Jorde, P., Espeland, S., André, C., \& Stenseth, C. (2011). Are low but statistically significant levels of genetic differentiation in marine fishes 'biologically meaningful'? A case study of coastal Atlantic cod. Molecular Ecology, 20, 768-783.

[16] Bohlmeyer, D. (1989). A protein electrophoretic analysis of population structure in the red drum (Sciaenops ocellatus). Texas: TESIS DOCTORAL.

[17] Hansen, M., Nielsen, E., \& Mensberg, K. (1997). The problem of sampling families rather than populations: relatedness among individuals in samples of juvenile brown trout Salmo trutta $\mathrm{L}$. Molecular Ecology, 6(5), 469-474.

[18] Grewe, P., Feutry, P., Hill, P., Gunasekera, R., Schaefer, K., Itano, D., Fuller, D., Foster, S. y Davies, C. (2015). Evidence of discrete yellowfin tuna (Thunnus albacares) populations demands rethink of management for this globally important resource. Scientific Reports, 5 (16916), 1-9. 